\title{
Amelogenesis imperfecta: therapeutic strategy from primary to permanent dentition across case reports
}

Steve Toupenay ${ }^{1}$, Benjamin Philippe Fournier ${ }^{1,2,3,4,5}$, Marie-Cécile Manière ${ }^{7,8}$, Chantal Ifi-Naulin ${ }^{1}$, Ariane Berdal ${ }^{1,2,3,4,5}$ and Muriel de La Dure- Molla $a^{1,4,6,9^{*}}$ (D)

\begin{abstract}
Background: Hereditary enamel defect diseases are regrouped under the name "Amelogenesis Imperfecta" (AlH). Both dentitions are affected. Clinical expression is heterogeneous and varies between patients. Mutations responsible for this multigene disease may alter various genes and the inheritance can be either autosomal dominant or recessive, or X-linked. Until now, no therapeutic consensus has emerged for this rare disease.

Case presentation: The purpose of this article was to report treatments of AlH patients from childhood to early adulthood. Treatment of three patients of 3, 816 years old are described. Each therapeutic option was discussed according to patients' age and type of enamel alteration. Paediatric crowns and resin based bonding must be preferred in primary teeth. In permanent teeth, non-invasive or minimally invasive dentistry should be the first choice in order to follow a therapeutic gradient from the less invasive options to prosthodontic treatments.

Conclusion: Functional and aesthetic issues require patients to be treated; this clinical care should be provided as early as possible to enable a harmonious growth of the maxillofacial complex and to prevent pain.
\end{abstract}

Keywords: Amelogenesis imperfecta, Dental care, Operative dentistry, Paediatric dentistry

\section{Background}

Amelogenesis imperfecta is a rare genetic disease affecting enamel. Primary and permanent teeth are concerned with almost the same severity. Differential diagnosis must be made with enamel developmental defects caused by environmental factors (fluoride, tetracycline???) [1] or traumatic etiologies as they will only affect defined teeth and rarely both dentitions. For example, experimental studies showed that molar incisor hypoplasia $(\mathrm{MIH})$, which only affects permanent incisors and first molars, might be caused by prenatal or early child exposure to endocrine disruptors [2].

Amelogenesis imperfecta presents large variability in its clinical expression. Mutations have been reported in different genes. Some of them encode for enamel proteins, either structural (amelogenin, enamelin,

* Correspondence: murielmolla@gmail.com

${ }^{1}$ Centre de référence des maladies rares orales et dentaires Orares, Hopital Rothschild, APHP, Paris, France

${ }^{4}$ Université Pierre et Marie Curie-Paris, F-75006 Paris, France

Full list of author information is available at the end of the article ameloblastin, c4orf26) or enzymatic (kallikrein 4, $M M P 20)$; some others encode for transcription factors (MSX2, DLX3), cellular proteins (WDR72, FAM83H, COL17A1), cellular receptor (ITGB6) and calcium carrier (SLC24A4) [3]. Until today, no relation between genotype and phenotype has been established. Enamel may be modified in its width, microstructure or mineralization degree. Thus, clinical symptomatology goes from light discoloration to disintegration/breakdown of the enamel of the entire tooth. Witkop's classification distinguished 4 different types: hypoplastic, hypomature, hypomineralized and hypomature with taurodontism forms, with 14 specific subtypes [4]. Indeed we differentiate 3 clinical entities: hypoplastic, hypomature and hypomineralized AI.

- Hypoplastic AIH (type I) consists of quantitative alteration of enamel with localized or generalized reduced thickness. Teeth are yellow to light brown, surface is rough with pits or larger area defects.

(c) The Author(s). 2018 Open Access This article is distributed under the terms of the Creative Commons Attribution 4.0 International License (http://creativecommons.org/licenses/by/4.0/), which permits unrestricted use, distribution, and reproduction in any medium, provided you give appropriate credit to the original author(s) and the source, provide a link to the Creative Commons license, and indicate if changes were made. The Creative Commons Public Domain Dedication waiver (http://creativecommons.org/publicdomain/zero/1.0/) applies to the data made available in this article, unless otherwise stated. 
Severe hypoplastic phenotype leads to morphological anomalies seen on radiographic examinations. No pain is associated with this AI, although some slight thermal sensitivity may sometimes be reported [5].

- Hypomature AIH (type II) consists of a defect in matrix protein degradation. In enamel, which is the most calcified structure in the organism, proteins must be degraded and removed to achieve final crystal growth. In type II, enamel appears white or brown, without translucency. Hardness during probing and thickness of enamel layer are normal. However, enamel breakdown often occurs. On radiographs, enamel opacity is decreased especially near the enamel dentin junction. This type of $\mathrm{AIH}$ is the mildest form and frequently undiagnosed. Aesthetics is the first cause of consultation [6].

- Hypomineralized AIH (type III) is the most severe AI form. Enamel mineral content is reduced causing pain while masticating, and brushing. Gingivitis and periodontal diseases have been described, with large amounts of dental calculus. Teeth are very sensitive to temperature and brushing. Enamel is dark yellow or brown. On radiographs, enamel and dentin may reach the same radiodensity [7]. Anxiety has often been reported in these patients due to permanent dental pain [8].

Other dental anomalies may be associated with AI [9]: taurodontism [10], pulp stones, delayed tooth eruption, anterior open bite or craniofacial anomaly [11, 12].
Surprisingly, no increased incidence of caries has been reported.

\section{Case presentation \\ Case report 1}

A three-year-old girl was referred to the Reference Centre of Rare Diseases in Paris. Her medical history was noncontributory. According to her mother, she complained with pain while eating, moderate sensitivity during tooth brushing and above all poor aesthetic aspect of her teeth. Intraoral examination revealed a hypoplastic AIH with yellow teeth and rough surfaces (Fig. 1a). Brown extrinsic discoloration was seen in the hypoplastic area. Enamel was reduced in thickness and severely hypoplastic, giving the idea of a false microdontia with multiple diastemas. Molars were the most affected teeth showing reduced crown height. In addition, anterior open bite was noted without thumb sucking. Treatment was planned following 3 objectives at this age:

- Pain prevention and treatment

- Protection of dental tissue integrity in order to maintain occlusal function and limit dental biofilm retention

- Restoration of smile aesthetics.

On primary molars, the choice of treatment was stainless steel crowns $\left(3 \mathrm{M}^{\mathrm{TM}} \mathrm{ESPE}^{\mathrm{TM}}\right)$ because the occlusal morphology was lost (Fig. 1b). This way, vertical dimension was slightly increased and maintained.
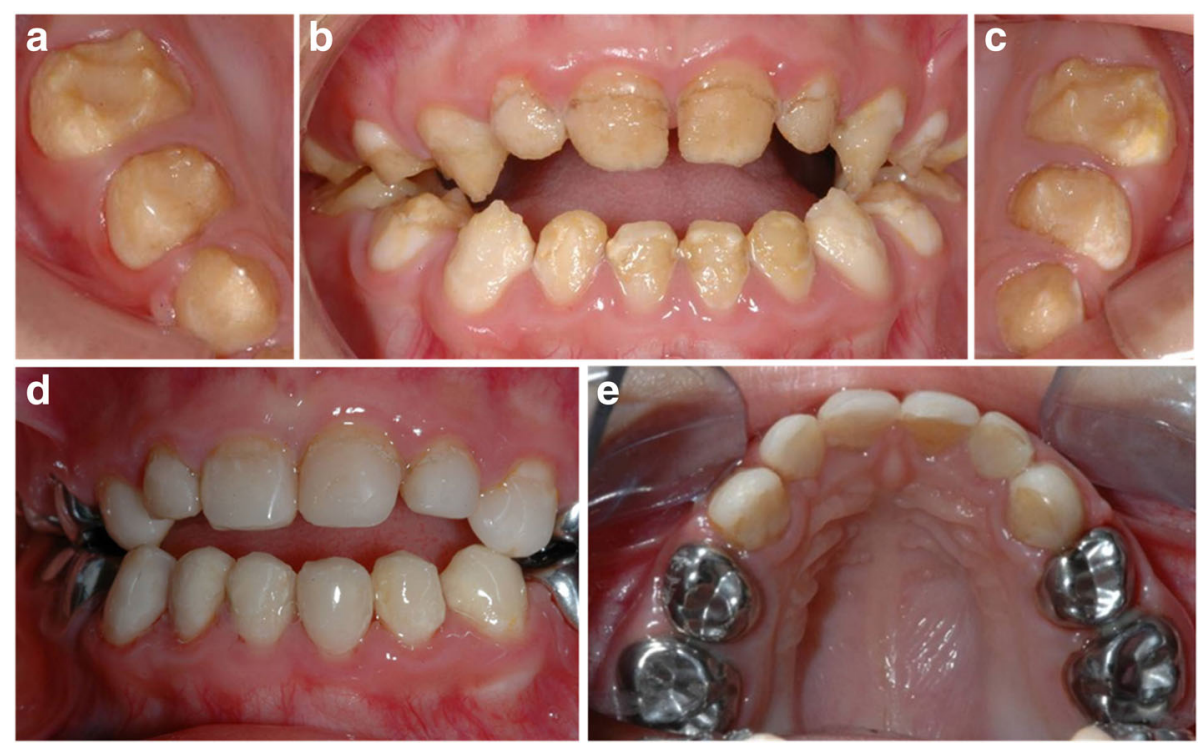

Fig. 1 4,5-year-old patient affected by hypomineralized Al. Clinical examination revealed pain during brushing and hot and cold sensitivity, open bite whithout digit sucking. a-c Enamel was yellow to brown, easily chipping, with loss of dental morphology. d, e Oral surgery was realized under local anesthesia through four visits. Stainless steel pediatric crowns were realized on primary molars, and direct composite restorations were done in anterior teeth 
The incisors and canines were isolated with a rubber dam and direct dental composite restorations were placed (Herculite, Kerr [13, 14] with ER2 adhesives Optibond SL). Teeth were not prepared; we etched with 35\% Phosphatidic acid for $30 \mathrm{~s}$, rinsed for $30 \mathrm{~s}$ with air and water. Then teeth were air dried, adhesive was applied with an applicator tip, excesses were removed with air before polymerization for $45 \mathrm{~s}$. Affected enamel was not removed but bonding was directly applied to it. As enamel surface appeared rough, a flow composite (Tetric Evoflow, Ivoclar) was applied and served as intermediate material. Its higher fluidity and wettability would allow penetrating enamel roughness (Fig. 1b). Because tooth morphology of anterior teeth was not severely altered, "Odus" molds were not useful to offer a correct restoration. Composite resins were applied in one layer. Finishing and polishing were achieved with abrasive discs (Sof-lex/ 3 M ESPE). Patient follow-ups were done 6 months and 1 year after treatment. Composite sealing and oral hygiene were controlled.

\section{Case report 2}

An 8-year-old patient referred to the Reference Centre of Rare Diseases, Paris. Her medical and familial history revealed no etiologic explanation. Her main complaint was extreme sensitivity to hot and cold and she was anxious about dental care for this reason. Oral clinical exam showed a mixed dentition, with eruption of permanent incisors and first molars. Hypomineralized AI was diagnosed (Fig. 2a). Enamel was dark yellow in permanent teeth and brown in primary teeth. Some enamel breaks were observed in posterior teeth. A severe open bite was observed, associated with only occlusal contacts on first permanent molars and second primary molars. Maxillary bone showed insufficient transversal growth. Facial and oral functional exams revealed buccal breathing and nocturnal snoring explaining the ectopic maxillary lateral incisor eruption in the vestibular area. The patient was referred to the otorhinolaryngology department to investigate obstructive sleep apnea syndrome. The panoramic radiograph showed a reduction in the enamel thickness as well as a similar X-ray density between hypomineralized AI and dentin (Fig.2c). The patient showed very low self-esteem because of her poor appearance. She reported bullying at school and didn't want to smile.

Multidisciplinary treatment objectives taken into account at this age were:

- Preservation of tooth integrity and vitality of permanent teeth emerged in the oral cavity

- Non-invasive rehabilitation that allowed evolution during growth
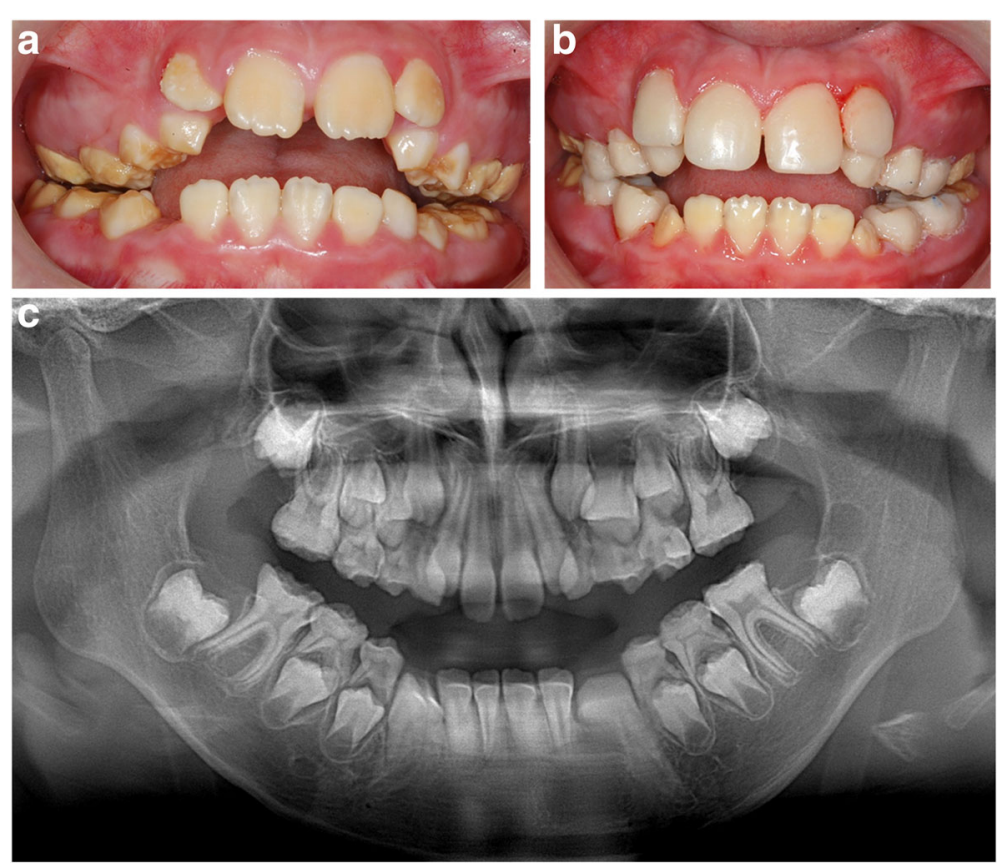

Fig. 2 8-year-old patient with hypomineralized Al. a Oral examination revealed brown enamel with severe breakdown in primary teeth. Patient history shows pain while eating, brushing and also breathing. Aesthetic complaint was high because of laughing at school. b Composite veneers and complete composite crowns were realised on anterior permanent teeth and posterior primary teeth respectively. c panoramic radiograph revealed severe reduction of enamel layer 
- Restoration of smile aesthetics

- Normalization of oral function (mastication, respiration, swallowing)

Because of the strong aesthetic request, full composite rehabilitation was decided (Fig. 2b). Master impression of the two arches was recorded with silicone material. Hard plaster (Type IV) was used, models were adjusted to a semi-adjustable articulator using a centric relation record. Rehabilitation of anterior teeth was done first in order to obtain the patient's confidence. This was workable because of the absence of anterior occlusion. Indirect resin-based composite (Premise Indirect System, Kerr) facets were performed on maxillary incisors without tooth cavity preparation. A layer of an opaque shade of composite was applied to mask the remaining spot. Composite resin A3 shade was used cervically, A2 in the core and A1 in the incisal edge. Careful polishing was made especially at the gingival border with a Touati bur. In primary teeth, full composite crowns were still build-up in plaster models. The restoration was bonded using dual cured composite resin (Variolink Esthetic, $\operatorname{Ivoclar}^{\mathrm{Tm}}$ Vivadent $\left.^{\mathrm{Tm}}\right)$. Occlusion was lightly increased to create enough space for this restorative reconstruction. Stainless steel crowns $\left(3 \mathrm{M}^{\mathrm{TM}} \mathrm{ESPE}^{\mathrm{TM}}\right)$ were applied to all first permanent molars without tooth preparation and sealed with glass ionomer cement. Orthopedic treatment followed to treat the maxillary hypoplasia.

\section{Case report 3}

A 16-year-old girl was referred by an orthodontist to the Reference Centre of Rare Diseases in Paris. Orthodontic treatment was performed with classical bracket technique in order to close anterior open bite (Fig. 3a-b). At the end of the treatment, the patient requested full mouth rehabilitation. She complained first of all about aesthetics but she also reported difficulties and painful chewing. Intraoral examination revealed hypomineralized AI associated with some hypoplasia. A little open bite remained after orthodontic treatment. Teeth were small with diastemas that were not closed as requested by the practitioner. In this occlusal context dental rehabilitation may be done without teeth reduction. Treatment was discussed according to several objectives taking into account the patient's age:

- Functional restoration

- Aesthetic restoration

- Lasting treatment

- Minimally invasive treatment

Master impression of the two arches was recorded with a silicone material and working cast was mounted onto a semi-adjustable articulator using a centric relation record. Composite veneers were applied on incisors and composite full crowns on all other teeth (Fig. 3c).
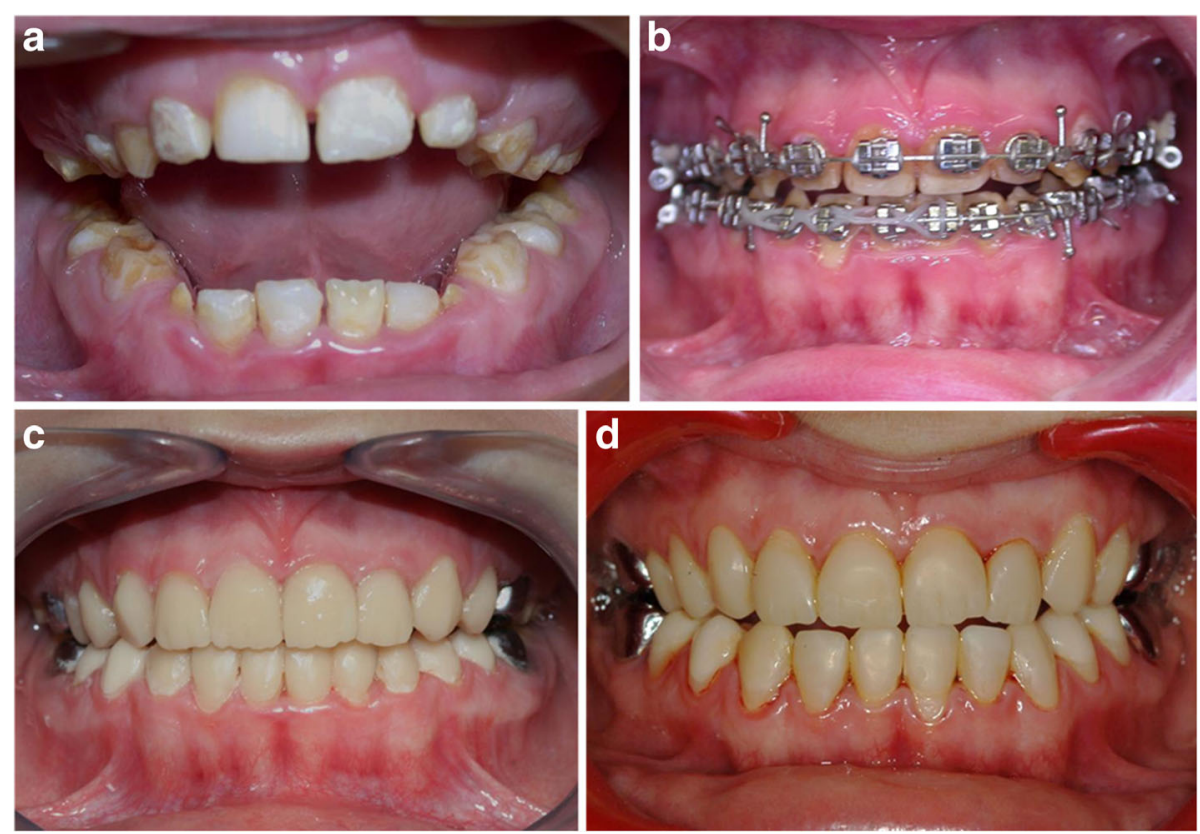

Fig. 3 Hypoplastic amelogenesis imperfecta associated to open bite patient (a): 9 years old was treated by an orthodontic treatment at 13 years old (b). At the end of the treatment, indirect composite restorations were realized with veneers on anterior teeth and full composite crowns on premolars (c: 16 years old). Stainless steel crowns had been previously realized on the first permanent molars at the age of 7 . View of the patient 5 years later $(\mathbf{d})$ 
Nanohybrid indirect composite (Premise Indirect System, Kerr) was used with dentin and enamel shades mimicking the clinical shade (A3 shade was used cervically, A2 in the core and A1 in the incisal edge). Each layer was polymerised. Rigorous polishing was done in order to obtain shiny surfaces (Tool kit, Kulzer). The restoration was bonded using dual cured composite resin (Variolink Esthetic, Ivoclar ${ }^{\mathrm{TMN}}$ Vivadent $^{\mathrm{TM}}$ ) taking care to separate each proximal contact with metal matrix. Carefully polishing was made especially at the gingival border with a Touati bur. The patient was very satisfied with the aesthetic appearance. She did not report any trouble with mastication. She was followed every 6 months. Oral hygiene and integrity of the restoration were scrupulously monitored. Direct composite was applied 3 years later, on the cervical part of the crown because gingival maturation occurred. She had only difficulty to control calculus deposition on the lingual part of mandibular incisors. Five years later, the restorations were still satisfactory (Fig. 3d).

\section{Discussion and conclusion}

Guidelines for AI treatment have been established by AAPD (American Academy of Pediatric Dentistry) [15]. Factors such as age, socio-economic conditions, AI type and severity have to be taken into account in treatment planning. Patients' first appointment usually corresponded to establishment determining the age of primary, mixed and permanent dentitions (that is 4, 8 and 13 year-old, respectively), and the two main demands were pain and aesthetics [16]. These patients suffered from reduced quality of life, social integration difficulties and loss of self-esteem [17]. Oral hygiene and rigorous follow-up are recommended. Hypomineralized enamel showed progress alteration with time because of its softness. Composite fillings can limit this degradation. Dental rehabilitation is still important to improve oral health in children. Rough enamel is associated with dental plaque retention, increasing gingival inflammation and pain. Hypomineralized enamel is the most severe form: once occlusion is established, teeth wear quickly inducing large tissue losses. Patients describe eating difficulties and pain when temperature changes. Thus, efficient tooth brushing cannot be achieved / tooth brushing cannot be effective. By contrast, hypoplastic AIs mainly present unsightly teeth complaints, while in hypomineralized type, local anesthesia is required for dental scaling.

Treatment should begin as soon as possible according to patient compliance in office dental care. For very young patients, general anesthesia may be necessary. Stainless steel crowns were indicated in primary teeth with hypoplastic or hypomineralized AI in order to reduce tooth sensitivity and restore enamel loss. Composite restorations were indicated for all primary teeth.
Previous studies regarding bonding to AI enamel were contradictory and varied with AI types [18, 19]. Some authors suggest complete enamel etching with sodium hypochlorite rinsing (5\% during $1 \mathrm{~min}$ ) in order to remove residual enamel proteins, especially in hypomature forms [20-22]. In vitro studies showed a decrease in bonding strength [23] while some others observed similar rupture strength values to healthy enamel ones. This latter may be explained by an increase of bonding area due to the microporosity of the affected enamel. Bonding on dentin is also different. Indeed, dentin in AI patients is more mineralized than usual, looking like reactional dentin with obliterated tubuli [24].

In mixed dentition, rehabilitation must be done as soon as teeth erupt. Treatment main goals should be the preservation of tooth integrity and vitality [25]. Paediatric crowns can be easily performed on first molars without tooth preparation, especially indicated when teeth are painful or hypoplastic. Orthodontic elastic spacer was used to separate teeth. In other cases, only prophylactic care may be enough. In hypomineralized forms, glass ionomer cements on occlusal surfaces were efficient in preventing pain and allowing temporizing until teeth eruption was achieved. Clinical follow ups should be planned every 6 months if new teeth erupt and every 9-12 months in stable periods. Orthodontic treatment is not contraindicated in AI patients. Brackets' bonding can be made with glass ionomer cements. Open bite prevalence is increased in AI patients. Treatment is often long and might need orthognatic surgery. In mild AI forms (without any pain or important hypoplasia), definitive rehabilitation should be planned only at the end of the orthodontic treatment. In other cases, primary restoration could be done before orthodontic treatment and reassessed at the end of the treatment.

In permanent dentition, different treatments from restorative to prosthetic rehabilitation have been reported in the literature [26] (Table 1). Nevertheless, no consensus between several case reports has been reached. Before adhesive dentistry and full ceramic material arrival, prosthetic treatment with ceramic crowns was done on all teeth. This kind of treatment is no longer recommended today for young adult. Most aesthetic results were obtained with fixed prosthodontics and all ceramic restorations showed good success rates [27]. However, teeth, especially anterior teeth, have to be devitalized, which decreases their longevity. Veneers were also done on anterior teeth in order to preserve dental tissues [28-32]. Their major disadvantage is their cost and the fact that their placement is time consuming [30].

Some authors proposed overdenture treatments [33]. In this case, occlusion and aesthetics were restored quickly. This kind of treatment is an option in mixed or 
Table 1 Advantages and disadvantages of the therapeutic alternatives in Al dental treatment

\begin{tabular}{|c|c|c|c|}
\hline & Advantages & Inconveniences & References \\
\hline Fixed Prosthodontics & $\begin{array}{l}\text { Aesthetics } \\
\text { Occlusion } \\
\text { Mechanical properties }\end{array}$ & $\begin{array}{l}\text { Invasive } \\
\text { Long treatment } \\
\text { Tooth vitality } \\
\text { Cost }\end{array}$ & $\begin{array}{l}\text { Robinson et al., } 2006 \text { [32] } \\
\text { Gisler et al., } 2010 \text { [30] } \\
\text { Chan et al., } 2011 \text { [28] } \\
\text { Ramos et al., } 2011 \text { [31] }\end{array}$ \\
\hline Removable Prosthodontics & $\begin{array}{l}\text { Fast } \\
\text { Occlusion } \\
\text { Cost effective }\end{array}$ & $\begin{array}{l}\text { Transitory } \\
\text { Hygiene } \\
\text { Retention issues }\end{array}$ & Zarati et al., 2009 [33] \\
\hline $\begin{array}{l}\text { Resin Based Composites - } \\
\text { Direct Restoration }\end{array}$ & $\begin{array}{l}\text { Correct aesthetics } \\
\text { Non invasive } \\
\text { Cost effective }\end{array}$ & $\begin{array}{l}\text { Mechanical } \\
\text { properties } \\
\text { Longevity? } \\
\text { Occlusion } \\
\text { regulation }\end{array}$ & Sockalingam S, 2011 [44] \\
\hline $\begin{array}{l}\text { Resin Based Composites- } \\
\text { Indirect Restoration }\end{array}$ & $\begin{array}{l}\text { Minimally Invasive } \\
\text { Aesthetics (stratification, opacity) } \\
\text { Mechanical properties } \\
\text { Easy to repair } \\
\text { Bite set up on simulator }\end{array}$ & $\begin{array}{l}\text { Durability? } \\
\text { Wear }\end{array}$ & $\begin{array}{l}\text { Manhart J et al., } 2000 \text { [45] } \\
\text { Koyuturk AE et al., } 2013 \text { [46] }\end{array}$ \\
\hline $\begin{array}{l}\text { Resin Based Composites- } \\
\text { Indirect Restoration } \\
\text { CAD-CAM }\end{array}$ & $\begin{array}{l}\text { Same as above } \\
\text { Possibility to use new polymer } \\
\text { infiltrated ceramic network materials } \\
\text { single office appointment }\end{array}$ & $\begin{array}{l}\text { Same as above } \\
\text { Steep Learning } \\
\text { curve } \\
\text { Occlusion }\end{array}$ & $\begin{array}{l}\text { Fasbinder DJ, } 2006 \text { [47] } \\
\text { Schlichting LH1 et al., } 2011 \text { [48] }\end{array}$ \\
\hline
\end{tabular}

young permanent dentition in order to wait for growth end. Still, overdentures should be transitory options since long term failures due to retention loss are frequent [34].

Direct or indirect [35-38] dental composites constitute other treatment options. These materials allow an aesthetic result with good long term outcomes and minimally invasive intervention [39]. Clinical reports showed short term follow-ups. Only two articles presented data with a longer follow-up [40]. Nevertheless in AI patients, the failure rate seemed to be increased compared to unaffected patients [41] or to the other dental abnormalities (for example: oligodontia or palatal clefts [42, 43]). This may be due to the less shear bond strength reported in AI teeth. A consensus protocol on AI enamel and dentin bonding is still to be decided.

AI is a rare inherited enamel disease, which explains the absence of evidence-based clinical recommendation and makes AI treatment challenging. Aesthetics, pain or tooth breakdown were the major patient complaints. Restorative to prosthodontic dentistry must be done in order to maintain oral function and growth preventing tooth loss and allowing oral hygiene maintenance. The first consultation must be as early as possible. Treatment alternatives deal with minimal invasive dentistry with the objective of maintaining tooth vitality as long as possible. The goal is to achieve therapeutic answer during the entire patient's life. In this respect, establishing a good trust relationship between child and dentist is critical. Genetic and biological knowledge of AI physiopathology is also helpful in treatment plan decision.

\section{Abbreviations}

AAPD: (American Academy of Pediatric Dentistry; Al: Amelogenesis imperfecta

\section{Acknowledgements}

We thank all the patients and their families for their participation and contribution to spreading our expert experiences of this specific dental care. We thank Miss Françoise Laveille for English reviewing.

\section{Funding}

This paper deals with patient treatment at the Rare Disease Reference Center in Rothschild Hospital (Paris). There are no conflicts of interest and no funding involved. Patients were treated by authors. Patients' consents were obtained to publish.

Availability of data and materials

All data were in the article and available.

Authors' contributions

ST and MDLD did surgery of patients; MDLD and BPF wrote the manuscript; MCM, CIN and AB have corrected the text. All authors read and approved the final manuscript.

\section{Authors' information}

Patients received all information about their care taking into account the latest knowledge in literature.

\section{Ethics approval and consent to participate}

Patients have approved surgery according to updated knowledge in pediatric dentistry. As patients were not part of a study but received routine dental care, Ethics committee assessment was not necessary.

\section{Consent for publication}

Written consents of all patients, relative to photograph and publication were obtained.

Competing interests

The authors declare that they have no competing interest.

\section{Publisher's Note}

Springer Nature remains neutral with regard to jurisdictional claims in published maps and institutional affiliations. 


\section{Author details}

'Centre de référence des maladies rares orales et dentaires Orares, Hopital Rothschild, APHP, Paris, France. ${ }^{2}$ UFR d'Odontologie, Université Paris-Diderot, F-75006 Paris, France. ${ }^{3}$ Université Paris-Descartes, F-75006 Paris, France. ${ }^{4}$ Université Pierre et Marie Curie-Paris, F-75006 Paris, France. ${ }^{5}$ Centre de Recherche des Cordeliers, INSERM UMRS 1138, Laboratory of Molecular Oral Pathophysiology, F-75006 Paris, France. ${ }^{6}$ INSERM UMR_S1163 Bases moléculaires et physiopathologiques des ostéochondrodysplasies, Institut Imagine, Necker, Paris, France. 'Hôpitaux Universitaires de Strasbourg, Pôle de Médecine et Chirurgie Bucco-Dentaires, Centre de Référence des Maladies Rares Orales et Dentaires, CRMR O-Rares, Strasbourg, France. ${ }^{8}$ Faculté de Chirurgie Dentaire, Université de Strasbourg, Strasbourg, France. ${ }^{9}$ Odontology Department, Rothschild Hospital, 5 rue Santerre, 75012 Paris, France.

Received: 21 July 2016 Accepted: 22 May 2018

Published online: 15 June 2018

\section{References}

1. Slayton RL, Warren JJ, Kanellis MJ, Levy SM, Islam M. Prevalence of enamel hypoplasia and isolated opacities in the primary dentition. Pediatr Dent. 2001;23:32-6.

2. Jedeon K, De la Dure-Molla M, Brookes SJ, Loiodice S, Marciano C, Kirkham J, Canivenc-Lavier MC, Boudalia S, Berges R, Harada H, et al. Enamel defects reflect perinatal exposure to bisphenol A. Am J Pathol. 2013;183:108-18.

3. Smith CEL, Poulter JA, Antanaviciute A, Kirkham J, Brookes SJ, Inglehearn CF, Mighell AJ. Amelogenesis Imperfecta; genes, proteins, and pathways. Front Physiol. 2017;8:435.

4. Witkop CJ Jr. Amelogenesis imperfecta, dentinogenesis imperfecta and dentin dysplasia revisited: problems in classification. Journal of oral pathology. 1988;17:547-53.

5. Wright JT, Robinson C, Kirkham J. Enamel protein in smooth hypoplastic amelogenesis imperfecta. Pediatr Dent. 1992;14:331-7.

6. Wright JT, Lord V, Robinson C, Shore R. Enamel ultrastructure in pigmented hypomaturation amelogenesis imperfecta. J Oral Pathol \& medicine : official publi of the Int Ass of Oral Pathologists and the Am Acad Oral Pathol. 1992;21:390-4

7. El-Sayed W, Shore RC, Parry DA, Inglehearn CF, Mighell AJ. Hypomaturation Amelogenesis Imperfecta due to WDR72 mutations: a novel mutation and Ultrastructural analyses of deciduous teeth. Cells Tissues Organs. 2009;85:699-705.

8. McDonald S, Arkutu N, Malik K, Gadhia K, McKaig S. Managing the paediatric patient with amelogenesis imperfecta. Br Dent J. 2012;212:425-8.

9. Poulsen S, Gjorup H, Haubek D, Haukali G, Hintze H, Lovschall H, Errboe M. Amelogenesis imperfecta - a systematic literature review of associated dental and oro-facial abnormalities and their impact on patients. Acta Odontol Scand. 2008:66:193-9.

10. Aldred MJ, Crawford PJ. Variable expression in Amelogenesis imperfecta with taurodontism. J Oral Pathol. 1988:17:327-33.

11. Pavlic A, Battelino T, Trebusak Podkrajsek K, Ovsenik M. Craniofacial characteristics and genotypes of amelogenesis imperfecta patients. Eur J Orthod. 2011;33:325-31.

12. Ravassipour DB, Powell CM, Phillips CL, Hart PS, Hart TC, Boyd C, Wright JT. Variation in dental and skeletal open bite malocclusion in humans with amelogenesis imperfecta. Arch Oral Biol. 2005;50:611-23.

13. de Souza-e-Silva CM, Parisotto TM, Steiner-Oliveira C, Gaviao MB, Nobre-DosSantos M. Oral rehabilitation of primary dentition affected by amelogenesis imperfecta: a case report. J Contemp Dent Pract. 2010;11:071-7.

14. Mackie IC, Blinkhorn AS. Amelogenesis imperfecta: early interception to prevent attrition. Dental update. 1991:18:79-80.

15. American Academy on Pediatric Dentistry Council on Clinical Affairs (2008-2009). Guideline on oral heath care/dental management of heritable dental development anomalies. Pediatr Dent 30, 196-201.

16. Parekh S, Almehateb M, Cunningham SJ. How do children with amelogenesis imperfecta feel about their teeth? Int J Paediatr D / Br Paedod Soc [and] the Int Assoc Dent Child. 2014;24:326-35

17. Coffield KD, Phillips C, Brady M, Roberts MW, Strauss RP, Wright JT. The psychosocial impact of developmental dental defects in people with hereditary amelogenesis imperfecta. J Am Dent Assoc. 2005:136:620-30.

18. Pugach MK, Ozer F, Li Y, Sheth K, Beasley R, Resnick A, Daneshmehr L, Kulkarni AB, Bartlett JD, Gibson CW, et al. The use of mouse models to investigate shear bond strength in amelogenesis imperfecta. J Dent Res. 2011;90:1352-7.
19. Seow WK, Amaratunge A. The effects of acid-etching on enamel from different clinical variants of amelogenesis imperfecta: an SEM study. Pediatr Dent. 1998;20:37-42

20. Saroglu I, Aras S, Oztas D. Effect of deproteinization on composite bond strength in hypocalcified amelogenesis imperfecta. Oral Dis. 2006;12:305-8.

21. Sonmez IS, Aras S, Tunc ES, Kucukesmen C. Clinical success of deproteinization in hypocalcified amelogenesis imperfecta. Quintessence Int. 2009;40:113-8.

22. Venezie RD, Vadiakas G, Christensen JR, Wright JT. Enamel pretreatment with sodium hypochlorite to enhance bonding in hypocalcified amelogenesis imperfecta: case report and SEM analysis. Pediatr Dent. 1994;16:433-6.

23. Faria, E.S.A.L., De Moraes, R.R., De Sousa Menezes, M., Capanema, R.R., De Moura, A.S., and Martelli-Junior, H. (2011). Hardness and microshear bond strength to enamel and dentin of permanent teeth with hypocalcified amelogenesis imperfecta. International journal of paediatric dentistry / the British Paedodontic Society [and] the International Association of Dentistry for Children. 2011;21:314-20

24. Sanchez-Quevedo MC, Ceballos G, Garcia JM, Luna JD, Rodriguez IA, Campos A. Dentine structure and mineralization in hypocalcified amelogenesis imperfecta: a quantitative X-ray histochemical study. Oral Dis. 2004;10:94-8.

25. Pires Dos Santos AP, Cabral CM, Moliterno LF, Oliveira BH. Amelogenesis imperfecta: report of a successful transitional treatment in the mixed dentition. J Dent Child. 2008;75:201-6.

26. Ng FK, Messer LB. Dental management of amelogenesis imperfecta patients: a primer on genotype-phenotype correlations. Pediatr Dent. 2009;31:20-30.

27. Pousette Lundgren G, Morling Vestlund Gl, Trulsson M, Dahllof G. A randomized controlled trial of crown therapy in young individuals with Amelogenesis Imperfecta. J Dent Res. 2015;94:1041-7.

28. Chan KH, Ho EH, Botelho MG, Pow EH. Rehabilitation of amelogenesis imperfecta using a reorganized approach: a case report. Quintessence Int. 2011:42:385-91.

29. Doruk C, Ozturk F, Sari F, Turgut M. Restoring function and aesthetics in a class II division 1 patient with Amelogenesis Imperfecta: a clinical report. European journal of dentistry. 2011;5:220-8.

30. Gisler V, Enkling N, Zix J, Kim K, Kellerhoff NM, Mericske-Stern R. A multidisciplinary approach to the functional and esthetic rehabilitation of amelogenesis imperfecta and open bite deformity: a case report. Journal of esthetic and restorative dentistry : official publication of the American Academy of Esthetic Dentistry [et al]. 2010:22:282-93.

31. Ramos AL, Pascotto RC, Iwaki Filho L, Hayacibara RM, Boselli G. Interdisciplinary treatment for a patient with open-bite malocclusion and amelogenesis imperfecta. American journal of orthodontics and dentofacial orthopedics : official publication of the American Association of Orthodontists, its constituent societies, and the American Board of Orthodontics. 2011;139:S145-53.

32. Robinson FG, Haubenreich JE. Oral rehabilitation of a young adult with hypoplastic amelogenesis imperfecta: a clinical report. J Prosthet Dent. 2006:95:10-3.

33. Zarati S, Ahmadian L, Arbabi R. A transitional overlay partial denture for a young patient: a clinical report. Journal of prosthodontics : official journal of the American College of Prosthodontists. 2009;18:76-9.

34. Saito M, Notani K, Miura Y, Kawasaki T. Complications and failures in removable partial dentures: a clinical evaluation. J Oral Rehabil. 2002;29:627-33.

35. Sabatini C, Guzman-Armstrong S. A conservative treatment for amelogenesis imperfecta with direct resin composite restorations: a case report. Journal of esthetic and restorative dentistry : official publication of the American Academy of Esthetic Dentistry [et al]. 2009;21:161-9. discussion 170

36. Brignall, I., Mehta, S.B., Banerji, S., and Millar, B.J. (2011). Aesthetic composite veneers for an adult patient with amelogenesis imperfecta: a case report. Dental update 38, 594-596, 598-600, 603.

37. Oliveira IK, Fonseca Jde F, do Amaral FL, Pecorari VG, Basting RT, Franca FM. Diagnosis and esthetic functional rehabilitation of a patient with amelogenesis imperfecta. Quintessence Int. 2011;42:463-9.

38. Turkun LS. Conservative restoration with resin composites of a case of amelogenesis imperfecta. Int Dent J. 2005;55:38-41.

39. Lygidakis NA, Chaliasou A, Siounas G. Evaluation of composite restorations in hypomineralised permanent molars: a four year clinical study. Eur J Paediatr Dent. 2003:4:143-8.

40. Lindunger A, Smedberg J. A retrospective study of the prosthodontic management of patients with amelogenesis imperfecta. Int J Prosthodont 2005;18:189-94. 
41. Pousette Lundgren G, Dahllof G. Outcome of restorative treatment in young patients with amelogenesis imperfecta. A cross-sectional, retrospective study. J Dent. 2014;42:1382-9.

42. Krieger O, Matuliene G, Husler J, Salvi GE, Pjetursson B, Bragger U. Failures and complications in patients with birth defects restored with fixed dental prostheses and single crowns on teeth and/or implants. Clin Oral Implants Res. 2009;20:809-16.

43. Incici E, Matuliene G, Husler J, Salvi GE, Pjetursson B, Bragger U. Cumulative costs for the prosthetic reconstructions and maintenance in young adult patients with birth defects affecting the formation of teeth. Clin Oral Implants Res. 2009;20:715-21.

44. Sockalingam S. Dental rehabilitation of amelogenesis imperfecta using thermoformed templates. J Indian Soc Pedod Prev Dent. 2011;29(1):53-6.

45. Manhart J, Neuerer P, Scheibenbogen-Fuchsbrunner A, Hickel R. Three-year clinical evaluation of direct and indirect composite restorations in posterior teeth. J Prosthet Dent. 2000;84(3):289-96.

46. Koyuturk AE, Ozmen B, Tokay U, Tuloglu N, Sari ME, Sonmez TT. Two-year follow-up of indirect posterior composite restorations of permanent teeth with excessive material loss in pediatric patients: a clinical study. J Adhes Dent. 2013;15(6):583-90.

47. Fasbinder DJ. Clinical performance of chairside CAD/CAM restorations. J Am Dent Assoc. 2006;137(Suppl:22S-31S). Review.

48. Schlichting LH1, Maia HP, Baratieri LN, Magne P. Novel-design ultra-thin CAD/CAM composite resin and ceramic occlusal veneers for the treatment of severe dental erosion. J Prosthet Dent. 2011;105(4):217-26.

Ready to submit your research? Choose BMC and benefit from:

- fast, convenient online submission

- thorough peer review by experienced researchers in your field

- rapid publication on acceptance

- support for research data, including large and complex data types

- gold Open Access which fosters wider collaboration and increased citations

- maximum visibility for your research: over $100 \mathrm{M}$ website views per year

At BMC, research is always in progress.

Learn more biomedcentral.com/submissions 